\title{
The Hunger Games: A Systematic Review of Pediatric Bariatric Surgery
}

\author{
Arianne N. Theodorous ${ }^{1}$, David M. Schwartzberg ${ }^{1}$ and Sathyaprasad C. Burjonrappa ${ }^{2,3,{ }^{*}}$ \\ ${ }^{1}$ Department of Surgery, Monmouth Medical Center, Long Branch, New Jersey 07740, USA \\ ${ }^{2}$ Department of Surgery, Children's Hospital of New Jersey, Newark, New Jersey 07112, USA \\ ${ }^{3}$ Albert Einstein College of Medicine, Bronx, NY, USA
}

\begin{abstract}
Introduction: As childhood obesity in the US reaches alarming levels, bariatric surgery is becoming a more commonly implemented treatment option due to its high success rate compared with behavioral modification and medical therapy alone. The mechanisms by which it affects body weight and metabolic homeostasis are not well understood. The goal of the present study was to perform a systematic review of pediatric bariatric surgery to evaluate its effectiveness in the context of the physiologic changes that are produced.

Materials and Methods: The PubMed database, MEDLINE, Springer Link, Cochrane, and article bibliographies were used to identify original English-language articles published between 2009 and 2014 evaluating pediatric patients. Included studies evaluated patients undergoing Roux en $\mathrm{Y}$ gastric bypass, laparoscopic sleeve gastrectomy or laparoscopic adjustable gastric banding and analyzed weight loss, BMI reduction, postoperative complications and comorbidity resolution post-procedure; all articles had at least a one year follow up.

Results: Five studies were included in our evaluation of the three most common bariatric procedures currently performed on the pediatric population for a total of 1,395 patients. The average patient age was 18.2 and $72 \%$ of patients were females. Most patients underwent roux en Y gastric bypass (RYGB) $(n=659)$, followed by laparoscopic adjustable gastric banding (LAGB) $(n=554)$ and finally laparoscopic sleeve gastrectomy (LSG) $(n=149)$. The greatest decrease in BMI was seen in the RYGB group who lost an average BMI of $16.7 \mathrm{~kg} / \mathrm{m}^{2}$, followed by the LSG group with a loss of $14.0 \mathrm{~kg} / \mathrm{m}^{2}$. The LAGB patients lost $8.2 \mathrm{~kg} / \mathrm{m}^{2}$. Postoperative complications varied in severity, however the only death occurred in a patient following RYGB.

Conclusion: Bariatric surgery has proven to reduce BMl and weight in the adolescent population resulting in an enhanced quality of life and resolution of significant co-morbidities. The mechanism of weight loss is different among the three most common procedures, as is their affect on gut hormone profiles. Ghrelin may have an effect on weight loss, however it is not solely responsible for the procedures' weight loss effect as levels vary postoperatively. RYGB has been shown to produce the greatest weight loss but postoperative ghrelin levels are not consistently decreased compared to LSG, which demonstrates low ghrelin levels routinely. Additional studies are needed to measure weight loss as it relates to postoperative gut hormone levels, as determining the physiologic changes after these procedures will guide future therapies.
\end{abstract}

Keywords: Adolescent Bariatric surgery, Outcomes, Ghrelin.

\section{INTRODUCTION}

The ongoing obesity epidemic in the United States will significantly impact the healthcare needs of the population and place a significant demand on the finite resources available to deal with its significant morbidity. The number of obese children and adolescents continues to rise in the United States, reaching nearly $17 \%$ in 2010 [1,2]. Approximately $4 \%$ of these children can be classified as extremely obese, with body mass index (BMI) measurements $\geq 99^{\text {th }}$ percentile for age $[3,4]$.

This translates into greater than 2 million children in the US who currently carry an increased risk of developing cardiovascular disease risk factors such as hypertension, hyperlipidemia, and metabolic disorders $[5,6]$. Studies have also linked childhood obesity to

*Address correspondence to this author at the Attending Pediatric Surgeon, Montefiore Medical Center, 111 East 210th Street, Bronx, NY, 10467, USA; Tel: 718920 7200; E-mail: sburjonr@montefiore.org

ISSN: 2223-3806 / E-ISSN: 1927-5951/15 higher rates of premature death, and adverse health effects in adulthood that are independent of adult BMI [7-10]. Detrimental effects on psychological health and quality of life have also been demonstrated, particularly in children with extreme obesity [11-13]. These factors have played a large part in the growing cost of healthcare in the US over the last 20 years, during which time the prevalence of obesity has doubled $[14,15]$. A study by Thorpe et al. estimated that between 1987 and 2001 the increase in obesity in the US accounted for $27 \%$ of the rise in health insurance spending $[16,17]$. These substantial physical, emotional and economic costs emphasize the need to identify effective strategies to prevent obesity beginning in childhood [18,19].

As a large volume of evidence now suggests that the path to obesity begins very early in life, research has focused on effective treatment during childhood [20-23]. Non-surgical interventions have included home and community based behavioral modification

(c) 2015 Lifescience Global 
strategies and pharmacologic interventions which have primarily shown little to moderate success [24-28]. There is some evidence, however, that intervention at a younger age has a more significant effect on weight loss. One study showed that children who began therapy before 10 years of age had a reduction in BMI that was greater than older children $[20,29]$. Behavioral therapy when begun in adolescence was not found to be successful in reducing BMI.

In contrast, bariatric surgery has been shown to be uniformly effective in reducing BMI, resolving certain co-morbidities and positively impacting quality of life in children and adolescents [4,30-34]. A recent metaanalysis showed clinically significant reduction in $\mathrm{BMI}$ after undergoing RYGB and LAGB procedures [31,35]. Cardiovascular risk factors have also been shown to improve, as evidenced by several studies showing improvements in glucose homeostasis, liver metabolism and reversible left ventricular hypertrophy [30,36-38]. In addition, the ongoing Teen-Longitudinal Assessment of Bariatric Surgery (Teen-LABS) has provided evidence to support the safety of weight loss surgery in even the most severely obese adolescents with multiple comorbidities $[39,40]$. The superior results observed after surgical intervention for obesity has expectedly led to a drastic increase in the number of bariatric procedures performed worldwide in the last 20 years [41,42]. In children, the procedure rate tripled from 2000 to 2003, but has since plateaued despite a continued upward trend in the number of adolescents who meet criteria for weight loss surgery $[7,43,44]$.

The evolution of pediatric bariatric surgery has reflected that of the adult population. While laparoscopic adjustable gastric banding (LAGB), rouxen-Y gastric bypass (RYGB), and laparoscopic sleeve gastrectomy (LSG) remain the most common procedures performed in both groups of patients, national trends reveal a decrease in RYGB and LAGB and an increase in LSG since $2008[40,45]$. These changes may be influenced by factors such as the high reoperation rate of $L A G B$, relative technical difficulty of RYGB and biliopancreatic diversion, and recent increase in insurance coverage of sleeve gastrectomy with a favorable risk-benefit profile [44,46-48]. The efficacy of newer procedures has been increasingly documented as long-term data becomes available, however, the majority of data currently pertain to RYGB as it is still the most common procedure performed worldwide [45].

Despite an increasing volume of literature documenting the benefits of bariatric surgery, there is still very little that is understood regarding the mechanisms by which they exert their effects. LAGB is the most commonly performed solely restrictive procedure for weight loss. It became increasingly used in older adolescents after its approval for the adult population in 2001, and in 2009 accounted for over one-third of all bariatric procedures in the US [44]. The procedure involves placement of an adjustable, removable cuff around the fundus of the stomach, thereby affecting weight loss presumably by caloric restriction alone. Roux-en-Y gastric bypass is the most commonly performed weight loss procedure in the world, comprising nearly half of all procedures performed in 2011 [45]. Weight loss is thought to be achieved primarily due to malabsorption of nutrients as they bypass the stomach and proximal small bowel; the degree of malabsorption depends on the length of the Roux limb. In addition, an approximately $15 \mathrm{~mL}$ gastric pouch is created, accounting for the restrictive portion of the procedure. Finally, laparoscopic sleeve gastrectomy is the newest of the three procedures. It has both restrictive and endocrine components due to the vertical excision of a large portion of the stomach along the greater curvature, including the majority of the fundus where ghrelin is produced.

It has been shown by several studies that procedures classified as malabsorptive or endocrine mediated (RYGB, biliopancreatic diversion, and sleeve gastrectomy) produce greater weight loss and resolution of comorbidities compared to purely restrictive procedures like LAGB $[49,50]$. A review by Batchelder et al. revealed that the greatest weight loss among patients undergoing bariatric surgery was observed following biliopancreatic diversion, followed by RYGB at up to $77 \%$ reduction in excess weight at 3 year follow-up. Laparoscopic sleeve gastrectomy achieved up to $85 \%$ excess weight loss at 5 years, and LAGB resulted in the least amount of weight loss at $68 \%$. Resolution of diabetes was observed in $82 \%$, $66 \%$, and $64 \%$ of patients following RYGB, LSG, and LAGB procedures, respectively [51]. These findings highlight the possibility of a more complex neurohormonal regulation of metabolic homeostasis than would be expected following pure caloric restriction. This has led to increased interest in better understanding the gut hormones which have key roles in regulating appetite and metabolism. Several of these have been shown to be altered in various ways by bariatric surgery and include ghrelin, PYY, GLP-1, and glucose-dependent insulinotropic polypeptide (GIP). While the data pertaining to the effects of weight loss surgery on these hormones remains somewhat 
inconsistent, the majority of recent studies have shown differences in alteration of gut hormones based on procedure type.

Examining outcomes of the three most common bariatric procedures currently performed for pediatric patients and relating them to the physiologic alteration they produce is the goal of the present study. In doing this, we hope to help identify the best strategies for the future success of pediatric bariatric surgery and the treatment of obesity.

\section{MATERIALS \& METHODS}

The indexed reference library PubMed, MEDLINE, Springer Link, and Cochrane were used to identify all articles from 2009 through 2014 focusing on pediatric bariatric surgery. Articles were limited to the English language from peer- reviewed sites. Searches consisted of keywords "pediatric," "adolescent," "bariatric surgery," "roux-en-y gastric bypass," "gastric banding," "laparoscopic gastric banding," "sleeve gastrectomy," "bilio-pancreatic diversion," "obese," and "morbid obesity." To meet inclusion criteria, the article must have measured an outcome related to bariatric surgery in a pediatric patient with a follow-up period of at least one year. Exclusion criteria consisted of any study that included patients over the age of twenty-one, studies without a significant follow up for the majority of their patients, and articles that were published prior to 2009. Additionally, only original retrospective and prospective studies were included in order to avoid duplication of results that were included in any previous meta-analysis.

Results have been divided into two main groups. Group 1 consists of studies focused on the safety and efficacy of commonly performed bariatric procedures, with end points being weight loss, BMI reduction, and complication rates. Studies in Group 2 have an endpoint of comorbidity resolution, quality of life improvement, or social dynamics that have shown benefits of pediatric bariatric surgery. The majority of the studies in Group 2 are not well powered, but they have documented additional benefits of these procedures and have added useful data to the current literature.

\section{Description of Procedures}

RYGB involves the restriction of the stomach to a small pouch of approximatley $15-30 \mathrm{ml}$ along the lesser curvature. The remainder of the stomach and proximal small bowel are excluded, and form the biliopancreatic limb which drains into the jejunum through an enteroenterostomy. A gastrojejunostomy is then created with the small gastric pouch to re-establish continuity, effectively bypassing a large portion of the foregut and leading to malabsorption.

During LSG, the majority of the fundus and body of the stomach are resected by firing a stapler vertically along the lesser curvature creating a small, tubular stomach. This procedure is restrictive, but to a lesser degree than RYGB. An endocrine response is also likely involved due to gastric greater curvature and fundus resection.

LAGB procedures are performed by placing a silicone band around the upper portion of the stomach. The band is connected to a subcutaneously placed port that is used to adjust the size of the band by either inflating or deflating the attached balloon. The procedure is restrictive in that it reversibly reduces stomach volume by creating a small superior gastric pouch.

\section{RESULTS}

\section{Group 1: BMI Reduction, Weight Loss, and Complications}

Five original articles met all criteria and were included in this review. Only one study (Lennerz et al) included all three of the common bariatric procedures (RYGB, LSG, LAGB) while the four remaining studies analyzed only one or two of the procedures and their respective outcomes [52-56]. Total accruement ranged from $n=18$ to $n=890$, with a mean patient population of 279 for all studies included $(n=18,61,81,345,890)$ (Table 1) [52-56]. Across all studies, individual procedure totals were $n=659$ for RYGB, $n=149$ for $L S G$ and $n=554$ for LAGB [52-56]. Follow up data was measured at multiple time intervals and for a varied length of time, however all studies included had a minimum of 1 year follow up (Table 2). Follow up data ranged from $37 \%$ to $100 \%$ at one year with decreasing follow up compliance over longer times intervals. Lennerz et al. had a 12 month follow up of $48 \%$ [53]. Nocca et al. had a 6 month follow up of $93 \%$ with a 12 month follow up of $78 \%$ [56]. Gothberg et al. had a $100 \%$ follow up at 12 months [52]. Messiah et al. had a 3 month follow up of $88 \%$ which fell to only $37 \%$ at 12 months [54]. Cozavoc et al. had an $83 \%$ follow up at 12 months [55]. Lennerz, Nocca, Gothberg and Cozacov et all had follow up times exceeding one year as the longer follow up period correlated with an increasing number of patients lost to follow up (Table 2) [52-56]. 
Table 1: Demographics: The Number of Patients as well as the Average Age and the Breakdown Ratio of Males: Females is Shown

\begin{tabular}{|c|c|c|c|c|}
\hline Name & Number of patients & Average Age & \% Male & \%emale \\
\hline \hline Lennerz et al. & 345 & 19.2 & $31 \%$ & $67 \%$ \\
\hline Nocca et al. & 61 & 19.5 & $35 \%$ & $69 \%$ \\
\hline Gothberg et al. & 81 & 16.5 & $25 \%$ & $75 \%$ \\
\hline Messiah et al. & 890 & 18.5 & $\mathbf{2 8 \%}$ & $\mathbf{2 8 \%}$ \\
\hline Cozacov et al. & 18 & 17.5 & $\mathbf{2 8 . 2}$ & $\mathbf{7 2 \%}$ \\
\hline TOTAL & $\mathbf{1 , 3 9 5}$ & $\mathbf{1 8 . 2}$ & \\
\hline
\end{tabular}

Table 2: Follow Up Period: The Follow Up Periods for the Five Included Studies are Shown. The Longer the Time Interval from the Operation, the More the Patients were Lost to Follow Up

\begin{tabular}{|c|c|c|c|c|c|c|}
\hline Name & $3 m$ & $6 m$ & $9 m$ & $12 \mathrm{~m}$ & $24 \mathrm{~m}$ & $>24 \mathrm{~m}$ \\
\hline Lennerz et al. & $x$ & $x$ & $x$ & $48 \%$ & $x$ & $22 \%$ \\
\hline Nocca et al. & $x$ & $93 \%$ & $x$ & $78 \%$ & $52 \%$ & $x$ \\
\hline Gothberg et al. & $x$ & $x$ & $x$ & $100 \%$ & $73 \%$ & $x$ \\
\hline Messiah et al. & $88 \%$ & $66 \%$ & $x$ & $37 \%$ & $x$ & $x$ \\
\hline Cozacov et al.* & $x$ & $x$ & $x$ & $83 \%$ & $72 \%$ & $56 \%$ \\
\hline AVERAGE & $88 \%$ & $80 \%$ & & $69 \%$ & $66 \%$ & $39 \%$ \\
\hline
\end{tabular}

*39\% 4 years, $17 \%>7$ years.

The ages of the patients ranged from 11 to 21 years old. Mean ages for each study were 16.5, 17.5, 18.5, 19.2 and 19.5 years old [52-56]. The male to female ratio showed a predominantly female patient population. Female subjects ranged from $65 \%$ to $74 \%$ of the total accruement $(65 \%, 65 \%, 69 \%, 72 \%$ and $74 \%$ for each study individually) (Table 1).

\section{Laparoscopic Adjustable Gastric Banding}

Two studies evaluated laparoscopic adjustable gastric banding (Graphs 1, 2, Table 3). Lennerz et al. accrued $34 \%$ of their total cohort from LAGB and showed a reduction of BMl of $-9.48+/-7.4 \mathrm{~kg} / \mathrm{m}^{2}$ (starting BMI $45.5 \mathrm{~kg} / \mathrm{m}^{2}$, reduced to $36.0 \mathrm{~kg} / \mathrm{m}^{2}$ ) and a weight loss of $28.2+/-22.5 \mathrm{~kg}$ (starting weight $135 \mathrm{~kg}$, reduced to $106 \mathrm{~kg}$ ) [53]. Intra-operative complications, postoperative fevers and peritonitis occurred in $0.9 \%$ of patients. "Other" post-operative complications were identified in $2.5 \%$ of patients.

Messiah et al. performed LAGB on $49 \%$ of patients included in their study [54]. Preoperative BMI was 46 $\mathrm{kg} / \mathrm{m}^{2}$ and the preoperative weight was $130.4 \mathrm{~kg}$. Postoperatively, the BMI dropped to $39.1 \mathrm{mg} / \mathrm{m}^{2}$ and the weight decreased to $110.7 \mathrm{~kg}$. The results showed a

\section{Average BMI Reduction Across All Studies}

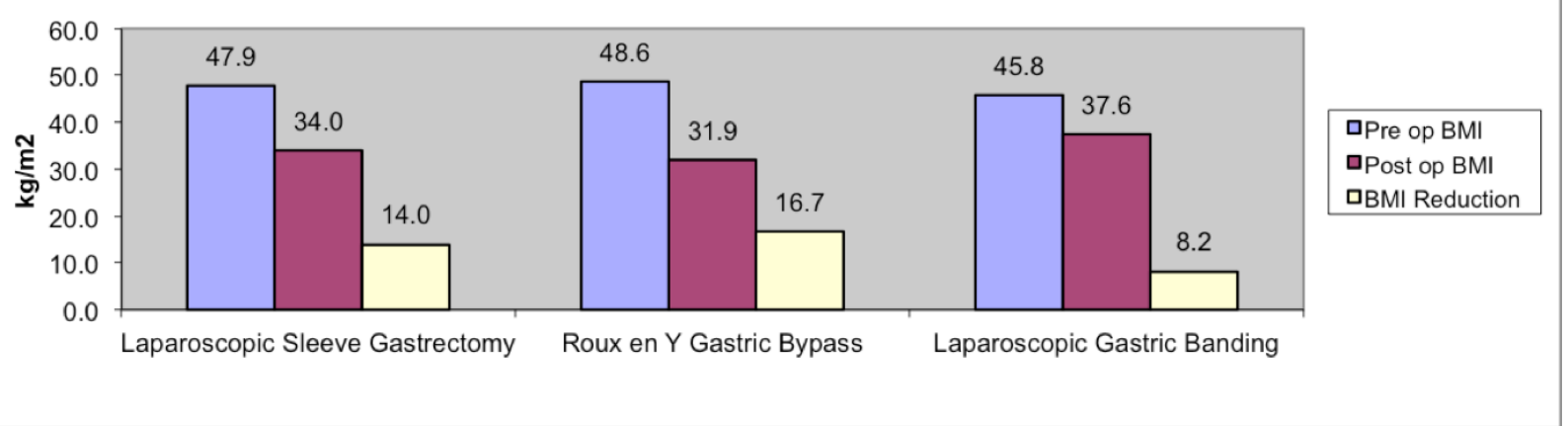

Graph 1: Depicts the average BMI $(\mathrm{kg} / \mathrm{m} 2)$ of each study that examined the different procedures. 


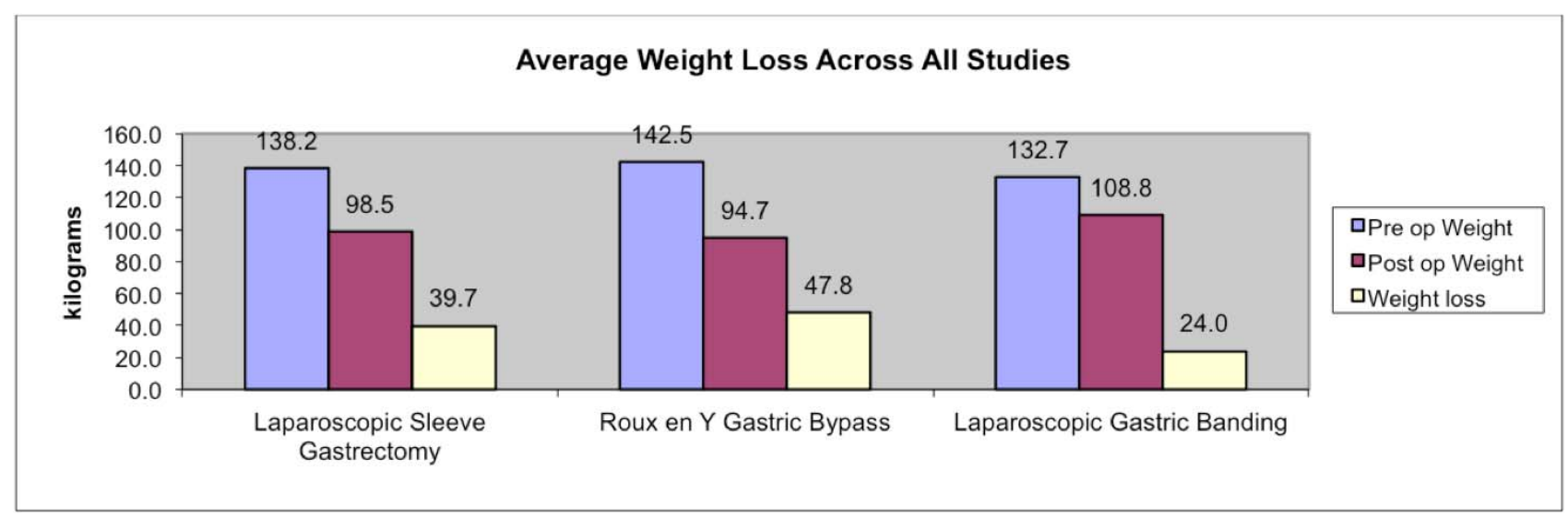

Graph 2: Average weight loss (in $\mathrm{kg}$ ) by procedure type.

Table 3: Summary of Laparoscopic Gastric Banding Results Including Pre-Operative and Post-Operative BMI \& Weight $(\mathbf{k g})$ as well as Post-Operative Events and Resolution of Co-Morbidities

\begin{tabular}{|c|c|c|c|c|c|c|c|c|c|c|c|}
\hline \multicolumn{12}{|c|}{ Laparoscopic Gastric B an ding } \\
\hline \multirow[t]{2}{*}{ Name } & \multirow{2}{*}{$\begin{array}{c}\% \text { of } \\
\text { Procedure }\end{array}$} & \multirow{2}{*}{$\begin{array}{l}\text { Pre } \\
\text { op } \\
\text { BMI }\end{array}$} & \multirow{2}{*}{$\begin{array}{l}\text { Pre op } \\
\text { Weight }\end{array}$} & \multirow{2}{*}{$\begin{array}{l}\text { Post } \\
\text { op } \\
\text { BMI }\end{array}$} & \multirow{2}{*}{$\begin{array}{l}\text { Post op } \\
\text { Weight }\end{array}$} & \multirow{2}{*}{$\begin{array}{c}\text { Time } \\
\text { of } \\
\text { results }\end{array}$} & \multicolumn{3}{|c|}{$\%$ of excess weight loss } & \multirow{2}{*}{$\begin{array}{l}\text { Pos Operative } \\
\text { Events }\end{array}$} & \multirow{2}{*}{$\begin{array}{c}\text { Co- } \\
\text { morbidities }\end{array}$} \\
\hline & & & & & & & $6 \mathrm{mo}$ & $12 \mathrm{mo}$ & $24 \mathrm{mo}$ & & \\
\hline Lennerz et al. & $34 \%$ & 45.5 & 135.0 & 36.02 & 106.8 & $x$ & $x$ & $\mathrm{x}$ & $\mathrm{x}$ & $\begin{array}{c}0.9 \% \text { other } \\
\text { intra op } \\
\text { complications/ } \\
\text { post op fever/ } \\
\text { post op } \\
\text { peritonitis, } \\
2.5 \% \text { other post } \\
\text { op } \\
\text { complications }\end{array}$ & $\mathrm{x}$ \\
\hline Nocca et al. & $0 \%$ & $\mathrm{x}$ & $x$ & $x$ & $\mathrm{x}$ & $\mathrm{x}$ & $\mathrm{x}$ & $x$ & $x$ & $\mathrm{x}$ & $x$ \\
\hline Gothberg et al. & $0 \%$ & $x$ & $x$ & $x$ & $x$ & $x$ & $x$ & $\mathrm{x}$ & $x$ & $x$ & $\mathrm{x}$ \\
\hline Messiah et al. & $49 \%$ & 46.0 & 130.4 & 39.1 & 110.7 & $12 \mathrm{mo}$ & $x$ & $\mathrm{x}$ & $x$ & $\begin{array}{c}41.0 \% \text { nausea/ } \\
\text { vomiting/ } \\
\text { intestinal } \\
\text { bleeding/ } \\
\text { diarrhea/ } \\
\text { gallstones; } \\
9.1 \% \\
\text { obstruction/ } \\
\text { abscess/ } \\
\text { internal hemia; } \\
25.0 \% \text { lap } \\
\text { chole; } 22.7 \% \\
\text { devise/ related } \\
\text { issue; } 2.3 \% \\
\text { readmission } \\
\text { rate; } 1.8 \% \\
\text { reoperation } \\
\text { rate }\end{array}$ & $\mathrm{x}$ \\
\hline Cozacov et al. & $0 \%$ & & & & & & $\mathrm{x}$ & $\mathrm{x}$ & $\mathrm{x}$ & $x$ & $\mathrm{x}$ \\
\hline Average & & 45.8 & 132.7 & 37.6 & 108.8 & & & & & & \\
\hline
\end{tabular}

$41.0 \%$ rate of nausea/ vomiting/ intestinal bleeding/ diarrhea or gallstones but their severity was not recorded. General complications were recorded as obstruction/abscess/internal hernia and occurred in $9.1 \%$ of patients. One quarter of all reoperations were due to laparoscopic cholecystectomy, while the remainder of operations consisted of revising or removing the band or port. Device-related complications were observed in $22.7 \%$ of patients. Slightly greater than seven percent of patients had a slipped gastric band. There was a $2.3 \%$ readmission rate as well as a $1.8 \%$ reoperation rate [54].

\section{Laparoscopic Sleeve Gastrectomy}

Laparoscopic sleeve gastrectomy patients saw a significant weight and BMI reduction after surgery 
Table 4: Summary of Laparoscopic Sleeve Gastrectomy Results Including Pre-Operative and Post-Operative BMI \& Weight (kg) as well as Post-Operative Events and Resolution of Co-Morbidities

\begin{tabular}{|c|c|c|c|c|c|c|c|c|c|c|c|}
\hline \multicolumn{12}{|c|}{ Laparoscopic Sleeve Gastrectomy } \\
\hline \multirow[t]{2}{*}{ Name } & \multirow{2}{*}{$\begin{array}{c}\% \text { of } \\
\text { Procedure }\end{array}$} & \multirow{2}{*}{$\begin{array}{l}\text { Pre } \\
\text { op } \\
\text { BMI }\end{array}$} & \multirow{2}{*}{$\begin{array}{l}\text { Pre op } \\
\text { Weight }\end{array}$} & \multirow{2}{*}{$\begin{array}{l}\text { Post } \\
\text { op } \\
\text { BMI }\end{array}$} & \multirow{2}{*}{$\begin{array}{c}\text { Post } \\
\text { op } \\
\text { Weight }\end{array}$} & \multirow{2}{*}{$\begin{array}{l}\text { Time } \\
\text { of } \\
\text { results }\end{array}$} & \multicolumn{3}{|c|}{$\%$ of excess weight loss } & \multirow{2}{*}{$\begin{array}{l}\text { Post Operative } \\
\text { Events }\end{array}$} & \multirow[t]{2}{*}{ Co-morbidities } \\
\hline & & & & & & & $6 \mathrm{mo}$ & $12 \mathrm{mo}$ & $24 \mathrm{mo}$ & & \\
\hline Lennerz et al. & $23 \%$ & 50.8 & 154.0 & 35.4 & 107.7 & $x$ & $x$ & $x$ & $x$ & $\begin{array}{c}4 \% \text { UTI, } 7 \% \text { post } \\
\text { op fever, } 1.3 \% \\
\text { general post op } \\
\text { complications } \\
\text { ("not defined), } \\
1.3 \% \text { post up } \\
\text { bleeding, } 4 \% \\
\text { gastric leak, } \\
2.5 \% \text { sepsis, } \\
1.3 \% \text { peritonitis, } \\
2.6 \% \\
\text { intraabdominal } \\
\text { abscess, } 1.3 \% \\
\text { wound } \\
\text { dehiscence, } \\
2.6 \% \text { wound } \\
\text { infection }\end{array}$ & $x$ \\
\hline Nocca et al. & $100 \%$ & 46.7 & 133.5 & $x$ & $x$ & & $48 \%$ & $67 \%$ & $78 \%$ & $\begin{array}{l}1 \text { gastric leak, } 2 \\
\text { hematomas, } 1 \\
\text { pneumonia, } 5 \\
\text { needed lap } \\
\text { chole, } 11 \text { vitamin } \\
\text { deficiency }\end{array}$ & $\begin{array}{c}70 \% \text { resolved OSA, } \\
85.7 \% \text { resolved } \\
\text { HTN, } 100 \% \\
\text { resolved type DM2 }\end{array}$ \\
\hline Gothberg et al. & $0 \%$ & $x$ & $x$ & $x$ & $x$ & $x$ & $x$ & $x$ & $x$ & $x$ & $x$ \\
\hline Messiah et al. & $0 \%$ & $x$ & $x$ & $x$ & $x$ & $x$ & $x$ & $x$ & $x$ & $x$ & $x$ \\
\hline Cozacov et al. & $56 \%$ & 46.2 & 127.0 & 32.5 & 89.3 & $\begin{array}{c}47.9 \\
\text { mo }\end{array}$ & $x$ & $x$ & $x$ & $\begin{array}{c}18 \% \text { LSG } \\
\text { converted to } \\
\text { RYGB } 1 \text { female } \\
\& 1 \text { male after } \\
\text { regained } 80 \text { \& } \\
50 \text { pounds } \\
\text { respectively, } \\
27 \% \text { had iron } \\
\text { deficiency } \\
\text { anemia, } 1 \% \text { had } \\
\text { GERD, } 1 \% \\
\text { diarrhea }+/- \\
\text { pain, } 1 \% \text { lap } \\
\text { chole, } 1 \% \\
\text { cholelithiasis } \\
\text { with pregnancy, } \\
9 \% \text { nausea with } \\
\text { over eating }\end{array}$ & $\begin{array}{c}100 \% \text { resolution } \\
\text { hypertension, DM2, } \\
\text { hypercholesteromia; } \\
75 \% \text { resolved } \\
\text { GERD, depression }\end{array}$ \\
\hline Average & & 47.9 & 138.2 & 34.0 & 98.5 & & & & & & \\
\hline
\end{tabular}

(Graphs 1, 2, Table 4). Nocca et al. showed that at 24 months, $78 \%$ of excess weight was lost in their study on sleeve gastrectomies [56]. Twenty-three percent of patients underwent LSG in Lennerz et als. cohort; postoperative BMI and weight were $35.4 \mathrm{~kg} / \mathrm{m}^{2}$ \& $107.7 \mathrm{~kg}$, respectively, compared to $50.8 \mathrm{~kg} / \mathrm{m}^{2}$ and $154 \mathrm{~kg}$ preoperatively [56]. Cozacov et al. similarly saw a BMI reduction of $13.7 \mathrm{~kg} / \mathrm{m}^{2}$ and an average weight loss of $37.7 \mathrm{~kg}$ at almost 50 months post-procedure in the $56 \%$ of patients who underwent LSG in their study [55].

Lennerz et al. saw a range of postoperative events that included $4 \%$ UTI rate, $1.3 \%$ postoperative bleeding occurrence, and a $4 \%$ gastric leak rate [53]. Additionally there was a $2.6 \%$ rate of wound infections and intra-abdominal abscesses. Nocca et al's. gastric leak and post-operative pneumonia rate occurred at $1.6 \%$, while hematomas occurred in $3.3 \%$ of patients [56] Five patients (8.2\%) underwent a laparoscopic cholecystectomy for symptomatic cholelithasis [56]. Eleven patients were reported to have had a vitamin deficiency.

Cozacov et al. reported 2 patients that needed a conversion from LSG to RYGB after a significant amount of weight was re-gained [55]. Twenty-seven percent of patients suffered iron deficiency, and another $9 \%$ of patients reported nausea with overeating. One percent of patients reported GERD, diarrhea, or required laparoscopic cholecystectomy due to cholelithiasis [55]. 
Table 5: Summary of Roux en Y Gastric Bypass Results Including Pre-Operative and Post-Operative BMI \& Weight (kg) as well as Post-Operative Events and Resolution of Co-Morbidities

\begin{tabular}{|c|c|c|c|c|c|c|c|c|c|c|c|}
\hline \multicolumn{12}{|c|}{ Roux en Y Gastric Bypass } \\
\hline \multirow[t]{2}{*}{ Name } & \multirow[t]{2}{*}{$\begin{array}{c}\% \text { of } \\
\text { Procedure }\end{array}$} & \multirow{2}{*}{$\begin{array}{c}\text { Pre op } \\
\text { BMI } \\
\left(\mathbf{k g} / \mathrm{m}^{2}\right)\end{array}$} & \multirow{2}{*}{$\begin{array}{c}\text { Pre op } \\
\text { Weight } \\
\text { (kg) }\end{array}$} & \multirow{2}{*}{$\begin{array}{c}\text { Post } \\
\text { op BMl } \\
\left(\mathbf{k g} / \mathbf{m}^{2}\right)\end{array}$} & \multirow{2}{*}{$\begin{array}{l}\text { Post op } \\
\text { Weight } \\
\text { (kg) }\end{array}$} & \multirow[t]{2}{*}{$\begin{array}{l}\text { Time of } \\
\text { results }\end{array}$} & \multicolumn{3}{|c|}{$\begin{array}{c}\% \text { of excess weight } \\
\text { loss }\end{array}$} & \multirow{2}{*}{$\begin{array}{c}\text { Post } \\
\text { Operative } \\
\text { Events }\end{array}$} & \multirow[t]{2}{*}{ Co-morbidities } \\
\hline & & & & & & & $6 \mathrm{mo}$ & $12 \mathrm{mo}$ & $24 \mathrm{mo}$ & & \\
\hline $\begin{array}{l}\text { Lennerz et } \\
\text { al. }\end{array}$ & $34 \%$ & 49.7 & 152.0 & 33.34 & 101.7 & $x$ & $x$ & $x$ & $x$ & $\begin{array}{l}0.9 \% \text { splenic } \\
\text { injury, vascular } \\
\text { injury, other } \\
\text { intraoperative } \\
\text { complication, } \\
\text { UTI, post op } \\
\text { fever, } \\
\text { anastamotic } \\
\text { stenosis, } \\
\text { wound } \\
\text { infection; } 1.7 \% \\
\text { pulmonary } \\
\text { complication }\end{array}$ & $x$ \\
\hline $\begin{array}{c}\text { Nocca et } \\
\text { al. }\end{array}$ & $0 \%$ & $\mathrm{x}$ & $x$ & $x$ & $x$ & $x$ & $\mathrm{x}$ & $x$ & $x$ & $x$ & $x$ \\
\hline $\begin{array}{l}\text { Gothberg } \\
\text { et al. }\end{array}$ & $100 \%$ & 45.5 & 133.0 & & $92.0 / 89.0$ & $12 \mathrm{mo} / 24 \mathrm{mo}$ & $\mathrm{x}$ & $\mathrm{x}$ & $\mathrm{x}$ & $\begin{array}{l}\text { In a } 5 \text { year } \\
\text { follow up: } 2.5 \% \\
\text { needed post } \\
\text { op pRBC } \\
\text { transfusion, } \\
1.2 \% \text { post up } \\
\text { fever, } 3.7 \% \\
\text { need post op } \\
\text { ileus operation, } \\
8.6 \% \text { need lap } \\
\text { chole, } 9.9 \% \\
\text { need lap } \\
\text { internal hernia }\end{array}$ & $x$ \\
\hline $\begin{array}{l}\text { Messiah et } \\
\quad \text { al. }\end{array}$ & $51 \%$ & 50.7 & 145.2 & 33.6 & 96.5 & $12 \mathrm{mo}$ & $x$ & $x$ & $x$ & $\begin{array}{c}1.0 \% \text { cardiac } \\
\text { failure resulting } \\
\text { in death; } \\
29.6 \% \text { nausea/ } \\
\text { vomiting/ } \\
\text { intestinal } \\
\text { bleeding/ } \\
\text { diarrhea/ } \\
\text { gallstones; } \\
16.3 \% \\
\text { obstruction/ } \\
\text { abscess/ } \\
\text { internal harnia; } \\
7.1 \\
\text { pneumonia/ } \\
\text { PE; } 20.8 \% \text { lap } \\
\text { chole; } 17.2 \% \\
\text { repair internal } \\
\text { hernia; } 6.9 \% \\
\text { SBO; } 3.4 \% \text { g- } \\
\text { tube; } 20.8 \% \\
\text { EGD wit }\end{array}$ & $x$ \\
\hline $\begin{array}{l}\text { Cozacov et } \\
\text { al. }\end{array}$ & $44 \%$ & 48.5 & 139.9 & 28.9 & 85.9 & $54.4 \mathrm{mo}$ & $x$ & $x$ & $x$ & $\begin{array}{c}18 \% \text { LSG } \\
\text { converted to } \\
\text { RYGB } 1 \\
\text { female \& } 1 \\
\text { male after } \\
\text { regained } 80 \text { \& } \\
50 \text { pounds } \\
\text { respectively, } \\
27 \% \text { had iron } \\
\text { deficiency } \\
\text { anemia, } 1 \% \\
\text { had GERD, } 1 \% \\
\text { diarrhea }+/- \\
\text { pain, } 1 \% \text { lap } \\
\text { chole, } 1 \% \\
\text { cholelithiasis } \\
\text { with pregnancy }\end{array}$ & $\begin{array}{c}100 \% \text { resolution } \\
\text { hypertension, DM2, } \\
\text { hypercholesteromia; } \\
75 \% \text { resolved } \\
\text { GERD, depression }\end{array}$ \\
\hline Average & & 48.6 & 142.5 & 31.9 & 94.7 & & & & & & \\
\hline
\end{tabular}




\section{Laparoscopic Roux-en-Y Gastric Bypass}

The most dramatic weight loss was seen following RYGB, which was evaluated in four of the included articles (Graphs 1, 2, Table 5). Gothberg et al. solely studied RYGB and saw an average weight loss of $41 \mathrm{~kg}$ and $89 \mathrm{~kg}$ at 12 and 24 months postoperatively [52]. After 5-year follow up of 81 patients, $13.5 \%$ required laparoscopic cholecystectomy while $9.9 \%$ underwent laparoscopic internal hernia repairs; there were no mortalities reported. Post-operative ileus was recorded in $3.7 \%$ of patients, and three out of four of those patients required a laparoscopic operation for correction of their pathology (operation details not defined). Packed cell transfusions were given in $2.5 \%$ of patients [52]. Fifty-one percent of patients in the study by Messiah et al. underwent RYGB [54]. Preoperative BMI and weight was recorded as $50.7 \mathrm{~kg} / \mathrm{m}^{2}$ and $154.2 \mathrm{~kg}$, respectively. At twelve months follow up the BMI was $33.6 \mathrm{~kg} / \mathrm{m}^{2}$ and the weight $96.5 \mathrm{~kg}$ showing an overall net loss in BMI of $17.1 \mathrm{~kg} / \mathrm{m}^{2}$ and a net weight loss of $57.7 \mathrm{~kg}$. In this study there was 1 cardiac failure-related death. Twenty-nine percent of patients were reported as experiencing nausea, vomiting or having intestinal bleeding, diarrhea, or gallstones. Of the patients with cholelithiasis, $20.8 \%$ of them needed a laparoscopic cholecystectomy. Obstruction, abscess, or internal hernia were noted in $16.3 \%$ of patients. Pneumonia and pulmonary embolus occurred at the same rate of $7.1 \%$ post-operatively. The highest percentage of reoperation $(24.1 \%)$ was defined as "other" and included reasons of abdominal pain, internal hernia, repair of lap-band tubing, diagnostic laparoscopy, lysis of adhesions, parenteral hernia repair, gastroparesis or internal hernia (no operation details reported). Nearly $7 \%$ of patients suffered a small bowel obstruction within 12 months of surgery and needed an operation. Esophogastroduodenoscopy with dilation was required in $20.8 \%$ of patients secondary to anastomotic stricture. The overall rate of re-operation in RYGB was $6.4 \%$ [52].

In Cozacov et al's. study, $44 \%$ of patients underwent RYGB, and their results show considerable weight loss as well [55]. Preoperative average BMI and weight was $48.5 \mathrm{~kg} / \mathrm{m}^{2}$ and $139.9 \mathrm{~kg}$, respectively. Postoperative averages were $28.9 \mathrm{~kg} / \mathrm{m}^{2}$ and $85.9 \mathrm{~kg}$ at a follow up of 54.4 months. One male and one female (18\% of patients) underwent conversion of a LSG to a RYGB due to weight gain; follow up weight loss from their second procedure was not recorded. Twentyseven percent of patients had postoperative iron deficiency anemia, $1 \%$ had gastroesophageal reflux disease (GERD), 1\% diarrhea and 1\% underwent laparoscopic cholecystectomy. Supplementary results show $100 \%$ resolution of hypertension, DM2 and hypercholesterolemia. Seventy-five percent of patients saw resolution of GERD and depression [55].

Lennerz et al. performed RYGB on 34\% of patients in their study [53]. Reported postoperative BMI and weight were $33.3 \mathrm{~kg} / \mathrm{m}^{2}$ and $101.7 \mathrm{~kg}$ compared to preoperative measurements of $49.7 \mathrm{~kg} / \mathrm{m}^{2}$ and $152 \mathrm{~kg}$, respectively. Postoperative complications were varied; $0.9 \%$ had a splenic injury, a vascular injury, or other intraoperative complications that were not specified. Urinary tract infections, postoperative fevers, anastomotic stenosis, wound infections, and pulmonary complications were reported in $1.7 \%$ of patients [53].

\section{Novel Operation: Gastric Plication}

Laparoscopic greater curvature plication has been established in the adult population but until recently has not been evaluated in the pediatric population. Vanguri et als. "Laparoscopic gastric plication in the morbidly obese adolescent patient" published in 2014 discusses the potential indications for plication and results of previous studies [57]. This restrictive, potentially reversible operation does not involve removal of tissue from the greater curvature of the stomach. Gastric plication is also considered a relatively safe procedure with complications ranging within the spectrum of all upper gastrointestinal surgery complications. The sparse complications that were seen post-operatively range from persistent vomiting from adhesions, liver hematomas, leaks at the suture line, and gastric perforation, which were all corrected by re-operation [57]. Zeinoddini et al. performed eight hundred gastric plication operations on a combination of adult and pediatric patients with only a $1 \%$ staple line leak rate [58]. There was an overall excess-weight loss of $42 \%$ over 10 years showing early success however all authors involved cited the need for additional studies $[57,58]$.

Calcaterra et al. from Italy published their results of robotic-assisted gastroplication of a 15 year old female with hyperinsulinism, hyperandrogenism, amenorrhea, polycystic ovarian syndrome, hypertension and left ventricular hypertrophy [59]. After an 18 month nonoperative trial of a multidisciplinary approach to control her weight and co-morbidities, her BMI increased from 28.8 to 42.2 , and surgery was then decided upon. At one month following surgery, her BMl decreased to 36.7, and her androgen profile, hyperinsulinism, and leptin levels all improved showing early success of the procedure [59]. 


\section{Group 2- Comorbidity Resolution}

Group 2 encompasses additional benefits of bariatric surgery examining studies that have observed outcomes other than total weight loss or BMI reduction. Improvement of comorbidities are additional advantages of bariatric surgery and favor adolescent baritric surgery to correct these problems in childhood. Comorbidities include, nonalcoholic fatty liver disease, type-1 diabetes mellitus, abnormal lipid profiles, elevated uric acid levels, hypertension and endothelial dysfunction, genetics and cardiovascular risks.

Holterman et al's. "Nonalcoholic fatty liver disease and bariatric surgery in adolescents" published in 2014 discussed the global impact of liver disease in the pediatric population [60]. Excluding viral, drug, autoimmune, or metabolic causes, the largely asymptomatic incidence of nonalcoholic fatty liver disease (NAFLD) approaches $80 \%$ in obese children while the general pediatric population has an incidence of $7-12 \%$. NAFLD will progress into cirrhosis in the minority of patients however there has been success with bariatric surgery thus far. Bariatric surgery showed improvement or resolution of steatosis in $90 \%$ of adults, although data in the adolescent population is lacking [60].

Performing bariatric surgery for adolescents with type 1 diabetes was documented in a study published in the Journal of the American Academy of Pediatrics by Chuang et al. in 2013 [61]. Two patients (13 and 19 years old) were operated on for diabetes refractory to medical management. Though treatment of type 2 diabetes with bariatric surgery has been established, this was the first study to look at adolescents with typeone diabetes. The 13 year old underwent RYGB while the 19 year old had a LSG. Both patients required less daily insulin and saw a decrease in their BMI by $42 \%$ and $28 \%$, respectively. Their hemoglobin A1C was unchanged although their cardiovascular risk factors and overall quality of life improved [61].

Impaired high density lipoprotein (HDL) function was assessed by Matsuo et al. in 2013 in the Journal of Obesity Biology and Intergrated Physiology [62]. HDL is a key regulator of endothelial function and its nitric oxide-vasodilatory effects. As HDL levels rise, abnormalities of this axis promote endothelial dysfunction, an early sign of atherosclerosis. The study revealed that neither RYGB nor lifestyle modification were able to correct the HDL dysfunction seen in the obese adolescent population. Further research is therefore needed for prevention of accelerated atherosclerosis in this patient population [62].
Oberbach et al's. pilot study hypothesized that serum uric acid levels would be elevated in obese adolescents which would relate to early development of insulin resistance, hypertension and endothelial dysfunction [36]. A small cohort of 10 patients underwent bariatric surgery (5 LSG v. 5 RYGB) and their serum uric acid, glucose, transaminases and lipids were measured preoperatively and 12 months post operatively compared to a control group. The BMI in the LSG group decreased from 46.4 to 34.4 ; the RYGB group decreased to 36.4 from 60 . The serum uric acid decreased by $31.1 \%$ and $28.5 \%$ after 12 months for the LSG and RYGB groups, respectively. The LSG group also saw normalization of triglycerides, insulin resistance and alanine aminotransferase levels while their blood pressure, fasting plasma glucose levels, and y-glutamyl transferase remained elevated. The RYGB patients showed fasting plasma insulin level, systolic blood pressure, and high-density lipoprotein level normalization [36].

"Weight loss after bariatric surgery in the morbidly obese adolescents with MC4R mutations" was published in 2013 to determine how the presence of the mutation would lend itself to weight loss after bariatric surgery [63]. Genetic factors play a strong role in obesity, specifically the G-protein MC4R receptor (melanocortin-4 receptor) in the hypothalamus and its influence on leptin production. Five patients were found to be heterozygous for the MC4R mutation out of 135 obese patients, ages 14-18, that were selected for the study. The majority of MC4R mutated individuals underwent LGB (v. LSG) although they were assigned at random. Mutated individuals were able to lose 46 to $95.3 \%$ of excess weight, which was not statistically significant compared to non-MC4R mutated patients. This illustrates that patients with and without MC4R mutations are able to lose weight with bariatric surgery [63].

Michalsky et al. studied the effects of a novel approach to accurately determining preoperative cardiac assessments in the obese adolescent population [37]. Transthoracic echocardiogram (TTE) has historically been used preoperatively for assessment of left ventricular hypertrophy or dilatation but often yields suboptimal results given the excessive amount of adipose tissue overlying the upper chest of obese patients. Using cardiac magnetic resonance (CMR) as a new diagnostic tool, Michalsky et al. have shown that certain risk factors for cardiovascular disease are reversed in adolescents following bariatric surgery. The 9 females in the study all had 
preoperatively measured adenosine-induced subendocardial ischemia at baseline, and all of them showed improvement after their weight loss surgery (60\% had normalization of ischemia, $40 \%$ showed partial improvement). CMR is unaffected by adipose deposits and may prove to become the standard in preoperative cardiac testing in obese individuals both preoperatively and for follow up [37].

\section{CONCLUSION}

In analyzing the three most commonly performed bariatric procedures for the pediatric population in the last 5 years, our results show that females undergo weight loss surgery almost three times more often than their male counterparts (1,004 vs. 391) and they most commonly undergo procedures between the ages of 16.5 and 19.5 (Table 1) [52-56]. While LSG has become an attractive option due to its relative simplicity, low complication rate, and demonstrated effectiveness, it did not display the greatest BMI and weight loss results [55]. Roux en $\mathrm{Y}$ gastric bypass yielded greater BMI and weight reduction across all studies, followed by laparoscopic sleeve gastrectomy and finally laparoscopic adjustable gastric banding (Graph 2). The average pre-surgery BMI for RYGB was 48.6 with a post-operative $\mathrm{BMI}$ of 31.9 yielding a loss of 16.7 BMI units. The pre and post-BMI results for LSG and LAGB were 47.9 and 34 , and 45.8 and 37.6 , respectively. Weight loss echoed the BMI results as RYGB produced the greatest weight loss $(47.8 \mathrm{~kg})$ compared to LSG (39.7 kg) and LAGB (24 kg) [52-56].

Although RYGB demonstrated the most significant weight loss, it was accompanied by more significant postoperative events including a $10 \%$ rate of readmission and up to a $17 \%$ rate of reoperation for internal hernias [52,54]. The overall rate for intraoperative complications was $2.6 \%$ for RYGB, which is more than triple the rate of LSG $(0 \%)$ and LAGB $(0.8 \%)$ combined, but this did not reach statistical significance $(\mathrm{P}=0.375) .53$ Complications that did reach statistical significance were specific post-operative complications in the LSG cohort $(P=0.075)$ which were higher than the post-operative complications secondary to RYGB; however there was no stratification on the severity of these complications [53]. Eleven patients underwent laparoscopic cholecystectomy secondary to gallstones following RYGB [52]. Cozacov et al. displayed two patients that underwent LSG and had significant weight gain requiring a RYGB for salvage. Post-operative events were recorded in all articles included in this review, ranging in complexity however without detail on surgical rescues for complications (Tables 3, 4, \& 5).
Novel ideas, represented in group 2, summarize newer literature that has expanded the discussion on pediatric bariatric surgery to include a focus on quality of life and resolution of co-morbidities. Emerging data supports offering obese patients access to counselors and mental-health providers as early as possible to avoid the detrimental effects obesity has in early childhood. Obese adolescents have reported their quality of life is comparable to adolescents diagnosed with cancer [64]. This is why a specialized team of dedicated individuals should care for obese adolescents as they can anticipate the evolving stresses their patients face [37,64]. Research has shown that obese individuals have a lower self-esteem and quality of life. However these issues resolve with weight loss and in only one year after bariatric surgery the perceived attractiveness and quality of life trended towards the norm [64]. Correction of the low selfesteem in the adolescent age group is a main proponent of early bariatric surgery along with the resolution of significant comorbidities.

Non-alcoholic fatty liver disease is the fastest growing indication for liver transplant in the adult population. Pediatric bariatric surgery resulted in a $90 \%$ reduction in steatosis, improving morbidity and future health care costs [60]. Comorbidities such as DM, OSA, and cardiovascular risk profiles including uric acid levels have improved following adolescent bariatric surgery $[36,61,65]$. Genetic research itself seems to be a marker of medical significance as genetics follows trends in the scientific community. Obesity is now a target of genetic research as the MC4R mutation, which is strongly associated with obesity, was hypothesized to be an obstacle for weight loss even after bariatric surgery. Although the study was underpowered, it showed that even with the MC4R mutation, there was no hindrance to children in losing weight after a bariatric procedure [63].

Our results and the observed differences between types of bariatric procedures with regard to efficacy and resolution of comorbidities may be more completely understood by examining the specific anatomic and physiologic changes that they produce. Laparoscopic adjustable gastric banding does not alter gastrointestinal anatomy, nor does it divert nutrients. Most of the reviewed literature has shown little to no effect on the postoperative gut hormone profile after LAGB, with the exception of ghrelin. Ghrelin is the only known orexigenic hormone produced in humans and has been shown to affect both short and long term regulation of energy homeostasis: increased appetite 
and food intake are observed immediately following release, while it has also been shown to increase adiposity and energy expenditure over time. Secreted primarily by X/A-like cells in the fundus of the stomach, it has generally been shown to increase after LAGB. Most investigators have recognized this paradoxical postoperative rise in the "hunger hormone" as a response to the weight loss experienced by patients after undergoing this purely restrictive procedure [66]. This may also help explain the relative lack of efficacy of this procedure as compared to RYGB and LSG. Glucose-dependent inulinotropic peptide (GIP), a polypeptide produced by K-cells in the proximal small bowel, potentiates insulin resistance and hyperglycemia. It affects lipid metabolism by stimulating lipogenesis and fatty acid synthesis and therefore contributes to adiposity [67]. It has been shown to remain unaffected after LAGB, as this procedure restricts only the upper portion of the stomach and maintains normal small bowel anatomy [68]. Glucagon-like peptide-1 (GLP-1) is also unchanged; this hormone, produced in the distal L-cells of the small bowel, is responsible for delayed gastric emptying, increased satiety, and maintenance of glucose homeostasis [69]. One study examined changes in the gut hormone peptide $Y Y$ (PYY) which has beneficial functions similar to GLP-1. This study by le Roux showed increased PYY levels following RYGB but no change in levels of the hormone following LAGB [70].

Studies evaluating the effects of RYGB on gut hormones generally conclude that it has positive effects. A review by Michalakis and le Roux determined GLP-1 and PYY levels were increased after RYGB and were higher than in patients who either underwent other types of bariatric surgery or who were nonoperated controls [71]. According to a review by Rao and Kini, the majority of studies evaluating GIP levels after RYGB have shown a postprandial decrease, with some studies also showing decreased levels during fasting [72]. This may be explained by the re-routing of oral intake that occurs after RYGB and the resulting exclusion of GIP-producing K-cells in the proximal small bowel. The effect of RYGB on ghrelin levels is less clear; several studies have shown decreased postoperative ghrelin levels but this is not consistently the case [73]. An attempt to clarify this disparity was made in a study by Sundbom et al., describing shortterm decreased ghrelin levels following RYGB that subsequently rise to normal levels by one year postoperatively [74]. They attribute this initial decrease in ghrelin levels to temporary vagal nerve trauma as they were careful to not transect the vagus nerves. Vagus nerve function has been shown to be directly related to ghrelin release as vagotomized patients were shown to experience no increased food intake after receiving exogenous ghrelin [75]. The authors concluded that since patients continued to experience weight loss despite increasing ghrelin levels, the weight loss observed after RYGB is independent of ghrelin functioning and may in fact be more directly related to vagal input [74].

LSG has been accepted relatively recently as an alternative bariatric procedure, and as such the data regarding its effects on gut hormones is not as extensive as that available for other procedures. The majority of the available data has pertained to its effects on ghrelin. Ghrelin levels have been shown to be reduced in procedures that either resected or sequestered the gastric fundus [69]. Although some studies show conflicting evidence, LSG appears to most consistently reduce ghrelin levels for an extended period of time. This was noted in a long term study by Bohdjalian et al., who reported outcomes 5 years postoperatively [76]. A prospective, double blinded study examined the effects of LSG and RYGB on appetite and PYY levels in addition to ghrelin; they found that both procedures had a similar positive effect on PYY levels, but LSG produced increased excess weight loss at 6 and 12 months compared to RYGB and also reduced appetite to a greater extent. Fasting and postprandial ghrelin levels were also significantly reduced after LSG while RYGB resulted in no change from baseline [77]. Another prospective study found significantly decreased ghrelin levels and increased PYY and GLP-1 levels after LSG [78]. A small, prospective study comparing the effects of LSG and RYGB on gut hormones found that both procedures had a similar positive effect on glucose tolerance, GLP1, GLP-2 and GIP levels after a standardized liquid meal [79].

What can be discerned from the seemingly inconsistent body of literature is that procedures that alter gastrointestinal anatomy (RYGB, LSG) tend to produce superior results to those that do not (LAGB). While both RYGB and LSG have both proven to be effective in reducing $\mathrm{BMI}$ and improving comorbidities in the pediatric population, they do not appear to work in similar ways. The majority of available data regarding LSG seems to indicate that its primary mechanism of action is to decrease ghrelin levels thereby reducing appetite and caloric intake, while RYGB is perhaps more effective yet seems to have no 
consistent long term effect on ghrelin. The factor responsible for the discrepancy between both procedure's effects on ghrelin may, in fact, be related to the preservation or inadvertent traumatic disruption of the vagus nerve. Despite these inferences, the intricacies of the gut hormone profile in relation to the alteration of anatomy produced by bariatric surgery is not yet well understood, particularly with respect to the pediatric population, and it remains unknown which physiologic manipulation or combination of these will be the most effective. Due to differences in surgical technique, perhaps the next step might be to measure differences in weight loss as it relates to postoperative gut hormone levels. The value of determining the basis for the efficacy of weight loss surgery lies in the potential for developing more successful and less invasive forms of intervention.

\section{DISCLOSURES}

The authors have none to report.

\section{REFERENCES}

[1] Choudhry MS, Rahman N, Boyd P. Duodenal atresia: associated anomalies, prenatal diagnosis and outcome 2009.

[2] Ogden CLC, Carroll MDM, Kit BKB, Flegal KMK. Prevalence of obesity and trends in body mass index among US children and adolescents, 1999-2010. JAMA 2012; 307(5): 483-490. http://dx.doi.org/10.1001/jama.2012.40

[3] Balistreri WF, Grand R, Hoofnagle JH, et al. Biliary atresia: current concepts and research directions. Summary of a symposium 1996.

http://dx.doi.org/10.1002/hep.510230652

[4] Inge $\mathrm{TH}$, Xanthakos SA, Zeller $\mathrm{MH}$. Bariatric surgery for pediatric extreme obesity: now or later? Int $\mathrm{J}$ Obes Relat Metab Disord 2007; 31(1): 1-14.

http://dx.doi.org/10.1038/sj.ijo.0803525

[5] May ALA, Kuklina EVE, Yoon PWP. Prevalence of cardiovascular disease risk factors among US adolescents, 1999-2008. Pediatrics 2012; 129(6): 1035-1041. http://dx.doi.org/10.1542/peds.2011-1082

[6] Weiss R, Dziura J, Burgert TS, et al. Obesity and the Metabolic Syndrome in Children and Adolescents. N Engl J Med 2004; 350(23): 2362-2374.

http://dx.doi.org/10.1056/NEJMoa031049

[7] Jolley SG, Kurlinski JP, Unger JL. Simultaneous correction of biliary atresia and small bowel atresia in the neonate 1992.

[8] Franks PW, Hanson RL, Knowler WC, Sievers ML, Bennett $\mathrm{PH}$, Looker HC. Childhood obesity, other cardiovascular risk factors, and premature death. N Engl J Med 2010; 362(6): 485-493.

http://dx.doi.org/10.1056/NEJMoa0904130

[9] Must A, Jacques PF, Dallal GE. Long-term morbidity and mortality of overweight adolescents: a follow-up of the Harvard Growth Study of 1922 to 1935. New England Journal 1992.

http://dx.doi.org/10.1056/NEJM199211053271904

[10] Reilly JJ, Kelly J. Long-term impact of overweight and obesity in childhood and adolescence on morbidity and premature mortality in adulthood: systematic review. Int J Obes Relat Metab Disord 2011; 35(7): 891-898.

http://dx.doi.org/10.1038/ijo.2010.222
[11] Reid JR. Practical imaging approach to bowel obstruction in neonates: a review and update 2011.

http://dx.doi.org/10.1053/j.ro.2011.07.003

[12] Kolotkin RL, Zeller M, Modi AC, et al. Assessing weightrelated quality of life in adolescents. Obesity (Silver Spring) 2006; 14(3): 448-457.

http://dx.doi.org/10.1038/oby.2006.59

[13] Zeller MH. Health-Related Quality of Life and Depressive Symptoms in Adolescents With Extreme Obesity Presenting for Bariatric Surgery. Pediatrics 2006; 117(4): 1155-1161. http://dx.doi.org/10.1542/peds.2005-1141

[14] Zimmer EZ, Bronshtein M. Early diagnosis of duodenal atresia and possible sonographic pitfalls 1996.

[15] Thorpe KE. Factors accounting for the rise in health-care spending in the United States: The role of rising disease prevalence and treatment intensity. Public Health 2006; 120(11): 1002-1007.

http://dx.doi.org/10.1016/j.puhe.2006.09.001

[16] George EK, Sutton AL. Bile duct anomalies associated with duodenal atresia; paradoxical presence of small bowel gas 1972.

[17] Thorpe KE, Florence CS, Howard DH, Joski P. The impact of obesity on rising medical spending. Health Aff (Millwood) 2004; Suppl Web Exclusives: W4-480-6. http://dx.doi.org/10.1377/hlthaff.w4.480

[18] Kao KJ, Fleischer R, Bradford WD. Multiple congenital septal atresias of the intestine: histomorphologic and pathogenetic implications 1983.

[19] Baidal JAW, Taveras EM. Childhood obesity: shifting the focus to early prevention. Arch Pediatr Adolesc Med 2012; 166(12): 1179-1181. http://dx.doi.org/10.1001/2013.jamapediatrics.358

[20] Savran B, Kocak A, Karakus YT, Durmaz Y, Deger AN Association of duodenal and biliary atresias in Martinez-Frias Syndrome: A very rare case. Journal of Pediatric Surgery Case Reports 2013; 1(4): 60-64. http://dx.doi.org/10.1016/j.epsc.2013.03.009

[21] Cunningham SA, Kramer MR, Narayan KMV. Incidence of Childhood Obesity in the United States. N Engl J Med 2014; 370(5): 403-411.

http://dx.doi.org/10.1056/NEJMoa1309753

[22] Gordon-Larsen P, Adair LS, Nelson MC, Popkin BM. Fiveyear obesity incidence in the transition period between adolescence and adulthood: the National Longitudinal Study of Adolescent Health. The American Journal 2004.

[23] Robbins JM, Khan KS, Lisi LM, Robbins SW, Michel SH, Torcato BR. Overweight among young children in the Philadelphia health care centers: incidence and prevalence. Arch Pediatr Adolesc Med 2007; 161(1): 17-20.

http://dx.doi.org/10.1001/archpedi.161.1.17

[24] Galán E. Intrauterine growth retardation, duodenal and extrahepatic biliary atresia, hypoplastic pancreas and other intestinal anomalies: further evidence of the Martinez-Frias 2007.

[25] Metcalf B, Henley W, Wilkin T. Effectiveness of intervention on physical activity of children: systematic review and metaanalysis of controlled trials with objectively measured outcomes (EarlyBird 54). BMJ 2012; 345: e5888.

[26] Showell NN, Fawole O, Segal J, et al. A Systematic Review of Home-Based Childhood Obesity Prevention Studies. Pediatrics 2013; 132(1): 193-200. http://dx.doi.org/10.1542/peds.2013-0786

[27] Bleich SN, Segal J, Wu Y, Wilson R, Wang Y. Systematic Review of Community-Based Childhood Obesity Prevention Studies. Pediatrics 2013; 132(1): 201-210. http://dx.doi.org/10.1542/peds.2013-0886

[28] McGovern L, Johnson JN, Paulo R, et al. Treatment of Pediatric Obesity: A Systematic Review and Meta-Analysis 
of Randomized Trials. J Clin Endocrinol Metab 2008; 93(12): 4600-4605

http://dx.doi.org/10.1210/jc.2006-2409

[29] Danielsson P, Kowalski J, Ekblom Ö, Marcus C. Response of severely obese children and adolescents to behavioral treatment. Arch Pediatr Adolesc Med 2012; 166(12): 11031108.

http://dx.doi.org/10.1001/2013.jamapediatrics.319

[30] Grosfeld JL, Rescorla FJ. Duodenal atresia and stenosis: reassessment of treatment and outcome based on antenatal diagnosis, pathologic variance, and long-term follow-up 1993. Available at: http://link.springer.com/article/10.1007/ BF01658696.

[31] Treadwell JR, Sun F, Schoelles K. Systematic Review and Meta-Analysis of Bariatric Surgery for Pediatric Obesity. Ann Surg 2008; 248(5): 763-776.

http://dx.doi.org/10.1097/SLA.0b013e31818702f4

[32] Alqahtani A, Alamri $\mathrm{H}$, Elahmedi $\mathrm{M}$, Mohammed $\mathrm{R}$. Laparoscopic sleeve gastrectomy in adult and pediatric obese patients: a comparative study. Surg Endosc 2012; 26(11): 3094-3100.

http://dx.doi.org/10.1007/s00464-012-2345-x

[33] Widhalm K, Fritsch M, Widhalm $\mathrm{H}$, et al. Bariatric surgery in morbidly obese adolescents: long-term follow-up. Int J Pediatr Obes 2011; 6(S1): 65-69. http://dx.doi.org/10.3109/17477166.2011.606817

[34] Lawson ML, Kirk S, Mitchell T, et al. One-year outcomes of Roux-en-Y gastric bypass for morbidly obese adolescents: a multicenter study from the Pediatric Bariatric Study Group. Journal of Pediatric Surgery 2006; 41(1): 137-43- discussion 137-43. http://dx.doi.org/10.1016/j.jpedsurg.2005.10.017

[35] Kimura K, Mukohara N, Nishijima E, Muraji T. Diamondshaped anastomosis for duodenal atresia: an experience with 44 patients over 15 years 1990 .

[36] Oberbach A, Neuhaus J, Inge T, et al. Bariatric surgery in severely obese adolescents improves major comorbidities including hyperuricemia. Metab Clin Exp 2014; 63(2): 242249.

http://dx.doi.org/10.1016/i.metabol.2013.11.012

[37] Michalsky MP, Raman SV, Teich S, Schuster DP, Bauer JA. Cardiovascular recovery following bariatric surgery in extremely obese adolescents: preliminary results using Cardiac Magnetic Resonance (CMR) Imaging. Journal of Pediatric Surgery 2013; 48(1): 170-177 http://dx.doi.org/10.1016/j.jpedsurg.2012.10.032

[38] Piché M-È, Martin J, Cianflone K, et al. Changes in predicted cardiovascular disease risk after biliopancreatic diversion surgery in severely obese patients. Metab Clin Exp 2014; 63(1): 79-86. http://dx.doi.org/10.1016/j.metabol.2013.09.004

[39] Okazaki T, Kobayashi H, Yamataka A, Lane GJ. Long-term postsurgical outcome of biliary atresia 1999.

[40] Inge $\mathrm{TH}$, Zeller $\mathrm{MH}$, Jenkins $\mathrm{TM}$, et al. Perioperative outcomes of adolescents undergoing bariatric surgery: the Teen-Longitudinal Assessment of Bariatric Surgery (TeenLABS) study. JAMA Pediatr 2014; 168(1): 47-53. http://dx.doi.org/10.1001/jamapediatrics.2013.4296

[41] Gallo A, Esquivel CO. Current options for management of biliary atresia 2013.

[42] Padwal R, Klarenbach S, Wiebe N, et al. Bariatric Surgery: A Systematic Review of the Clinical and Economic Evidence. J Gen Intern Med 2011; 26(10): 1183-1194. http://dx.doi.org/10.1007/s11606-011-1721-x

[43] Tsai WS, Inge TH, Burd RS. Bariatric surgery in adolescents: recent national trends in use and in-hospital outcome. Arch Pediatr Adolesc Med 2007; 161(3): 217-221. http://dx.doi.org/10.1001/archpedi.161.3.217

[44] Kelleher DC, Merrill CT, Cottrell LT, Nadler EP, Burd RS. Recent national trends in the use of adolescent inpatient bariatric surgery: 2000 through 2009. JAMA Pediatr 2013; 167(2): 126-132.

http://dx.doi.org/10.1001/2013.jamapediatrics.286

[45] Buchwald H, Oien DM. Metabolic/Bariatric Surgery Worldwide 2011 - Springer. Obes Surg 2013.

http://dx.doi.org/10.1007/s11695-012-0864-0

[46] O'Brien PE, Sawyer SM, Laurie C, Brown WA. JAMA Network | JAMA | Laparoscopic Adjustable Gastric Banding in Severely Obese Adolescents: A Randomized Trial. JAMA 2010.

[47] Buchwald $\mathrm{H}$, Avidor $\mathrm{Y}$, Braunwald $\mathrm{E}$, et al. Bariatric surgery: a systematic review and meta-analysis. JAMA 2004; 292(14): 1724-1737. http://dx.doi.org/10.1001/jama.292.14.1724

[48] Pallati P, Buettner S, Simorov A, Meyer A, Shaligram A Oleynikov D. Trends in adolescent bariatric surgery evaluated by UHC database collection. Surg Endosc 2012; 26(11): 3077-3081. http://dx.doi.org/10.1007/s00464-012-2318-0

[49] Kruger RS, Pricolo VE, Streeter TT, Colacchio DA, Andrade UA. A bariatric surgery center of excellence: operative trends and long-term outcomes. Journal of the American College of Surgeons 2014; 218(6): 1163-1174. http://dx.doi.org/10.1016/j.jamcollsurg.2014.01.056

[50] Buchwald H, Estok R, Fahrbach $\mathrm{K}$, et al. Weight and type 2 diabetes after bariatric surgery: systematic review and metaanalysis. Am J Med 2009; 122(3): 248-256.e5. http://dx.doi.org/10.1016/j.amjmed.2008.09.041

[51] Batchelder AJ, Williams R, Sutton C, Khanna A. The evolution of minimally invasive bariatric surgery. J Surg Res 2013; 183(2): 559-566

http://dx.doi.org/10.1016/j.jss.2013.02.036

[52] Göthberg G, Gronowitz E, Flodmark C-E, et al. Laparoscopic Roux-en-Y gastric bypass in adolescents with morbid obesity--surgical aspects and clinical outcome. Semin Pediatr Surg 2014; 23(1): 11-16.

http://dx.doi.org/10.1053/j.sempedsurg.2013.10.015

[53] Lennerz BS, Wabitsch M, Lippert $\mathrm{H}$, et al. Bariatric surgery in adolescents and young adults-safety and effectiveness in a cohort of 345 patients. Int J Obes Relat Metab Disord 2013; 38(3): 334-340.

http://dx.doi.org/10.1038/ijo.2013.182

[54] Messiah SE, Lopez-Mitnik G, Winegar D, et al. Changes in weight and co-morbidities among adolescents undergoing bariatric surgery: 1-year results from the Bariatric Outcomes Longitudinal Database. Surgery for Obesity and Related Diseases 2013; 9(4): 503-513.

http://dx.doi.org/10.1016/j.soard.2012.03.007

[55] Cozacov Y, Roy M, Moon S, et al. Mid-term results of laparoscopic sleeve gastrectomy and Roux-en-Y gastric bypass in adolescent patients. Obes Surg 2014; 24(5): 747752.

\section{http://dx.doi.org/10.1007/s11695-013-1169-7}

[56] Nocca D, Nedelcu M, Nedelcu A, et al. Laparoscopic sleeve gastrectomy for late adolescent population. Obes Surg 2014 24(6): 861-865

http://dx.doi.org/10.1007/s11695-014-1200-7

[57] Vanguri P, Brengman M, Oiticica C, Wickham EP, Bean MK, Lanning DA. Laparoscopic gastric plication in the morbidly obese adolescent patient. Semin Pediatr Surg 2014; 23(1): 24-30.

http://dx.doi.org/10.1053/..sempedsurg.2013.10.018

[58] Zeinoddini A, Heidari R, Talebpour M. Laparoscopic gastric plication in morbidly obese adolescents: a prospective study. Surgery for obesity and related diseases : official journal of the American Society for Bariatric Surgery 2014; 0(0). http://dx.doi.org/10.1016/j.soard.2014.02.039

[59] Calcaterra V, Cena H, Nakib G, et al. Robotic-assisted gastroplication in a morbidly obese adolescent: early 
improvement in metabolic and neurohormonal parameters. Pediatric Reports 2012; 4(4).

http://dx.doi.org/10.4081/pr.2012.e36

[60] Holterman A, Gurria J, Tanpure S, DiSomma N. Nonalcoholic fatty liver disease and bariatric surgery in adolescents. Semin Pediatr Surg 2014; 23(1): 49-57. http://dx.doi.org/10.1053/j.sempedsurg.2013.10.016

[61] Chuang J, Zeller MH, Inge T, Crimmins N. Bariatric surgery for severe obesity in two adolescents with type 1 diabetes. Pediatrics 2013; 132(4): e1031-4.

http://dx.doi.org/10.1542/peds.2012-3640

[62] Matsuo $\mathrm{Y}$, Oberbach A, Till $\mathrm{H}$, et al. Impaired HDL function in obese adolescents: impact of lifestyle intervention and bariatric surgery. Obesity (Silver Spring) 2013; 21(12): E68795. http://dx.doi.org/10.1002/oby.20538

[63] Censani $M$, Conroy $R$, Deng $L$, et al. Weight loss after bariatric surgery in morbidly obese adolescents with MC4R mutations. Obesity (Silver Spring) 2014; 22(1): 225-231. http://dx.doi.org/10.1002/oby.20511

[64] Aldaqal SM, Sehlo MG. Self-esteem and quality of life in adolescents with extreme obesity in Saudi Arabia: the effect of weight loss after laparoscopic sleeve gastrectomy. Gen Hosp Psychiatry 2013; 35(3): 259-264.

http://dx.doi.org/10.1016/..genhosppsych.2012.12.011

[65] Koeck ES, Barefoot LC, Hamrick M, Owens JA, Qureshi FG, Nadler EP. Predicting sleep apnea in morbidly obese adolescents undergoing bariatric surgery. Surg Endosc 2014; 28(4): 1146-1152. http://dx.doi.org/10.1007/s00464-013-3295-7

[66] Korner J, Inabnet W, Febres G, et al. Prospective study of gut hormone and metabolic changes after adjustable gastric banding and Roux-en-Y gastric bypass. Int $\mathrm{J}$ Obes Relat Metab Disord 2009; 33(7): 786-795. http://dx.doi.org/10.1038/ijo.2009.79

[67] Ionut V, Burch M, Youdim A, Bergman RN. Gastrointestinal hormones and bariatric surgery-induced weight loss 2013; 21(6): 1093-1103.

http://dx.doi.org/10.1002/oby.20364

[68] Shak JR, Roper J, Perez-Perez GI, et al. The effect of laparoscopic gastric banding surgery on plasma levels of appetite-control, insulinotropic, and digestive hormones. Obes Surg 2008; 18(9): 1089-1096.

http://dx.doi.org/10.1007/s11695-008-9454-6

[69] Gass M, Beglinger C, Peterli R. Metabolic surgery-principles and current concepts. Langenbecks Arch Surg 2011; 396(7): 949-972.

http://dx.doi.org/10.1007/s00423-011-0834-3
[70] le Roux CW, Aylwin SJB, Batterham RL, et al. Gut hormone profiles following bariatric surgery favor an anorectic state, facilitate weight loss, and improve metabolic parameters. Ann Surg 2006; 243(1): 108-114.

http://dx.doi.org/10.1097/01.sla.0000183349.16877.84

[71] Michalakis K, le Roux C. Gut hormones and leptin: impact on energy control and changes after bariatric surgery--what the future holds. Obes Surg 2012; 22(10): 1648-1657. http://dx.doi.org/10.1007/s11695-012-0698-9

[72] Rao RS, Kini S. GIP and Bariatric Surgery. Obes Surg 2010; 21(2): 244-252.

http://dx.doi.org/10.1007/s11695-010-0305-x

[73] Ochner CN, Gibson C, Shanik M, Goel V, Geliebter A. Changes in neurohormonal gut peptides following bariatric surgery. Int J Obes Relat Metab Disord 2010; 35(2): 153-166. http://dx.doi.org/10.1038/ijo.2010.132

[74] Sundbom M, Holdstock C, Engström BE, Karlsson FA. Early changes in ghrelin following Roux-en- $Y$ gastric bypass: influence of vagal nerve functionality? Obes Surg 2007; 17(3): 304-310. http://dx.doi.org/10.1007/s11695-007-9056-8

[75] le Roux CW, Neary NM, Halsey TJ, et al. Ghrelin Does Not Stimulate Food Intake in Patients with Surgical Procedures Involving Vagotomy. J Clin Endocrinol Metab 2005; 90(8): 4521-4524.

http://dx.doi.org/10.1210/jc.2004-2537

[76] Bohdjalian A, Langer FB, Shakeri-Leidenmühler S, et al. Sleeve gastrectomy as sole and definitive bariatric procedure: 5-year results for weight loss and ghrelin. Obes Surg 2010; 20(5): 535-540. http://dx.doi.org/10.1007/s11695-009-0066-6

[77] Karamanakos SN, Vagenas K, Kalfarentzos F, Alexandrides TK. Weight Loss, Appetite Suppression, and Changes in Fasting and Postprandial Ghrelin and Peptide-YY Levels After Roux-en-Y Gastric Bypass and Sleeve Gastrectomy. Ann Surg 2008; 247(3): 401-407. http://dx.doi.org/10.1097/SLA.0b013e318156f012

[78] Vincent RP, le Roux CW. Changes in gut hormones after bariatric surgery. Clin Endocrinol (Oxf) 2008; 69(2): 173-179. http://dx.doi.org/10.1111/j.1365-2265.2007.03164.x

[79] Romero F, Nicolau J, Flores L, et al. Comparable early changes in gastrointestinal hormones after sleeve gastrectomy and Roux-En-Y gastric bypass surgery for morbidly obese type 2 diabetic subjects. Surg Endosc 2012; 26(8): 2231-2239. http://dx.doi.org/10.1007/s00464-012-2166-y 